\title{
Profil Sumber Daya Perikanan di Kecamatan Pemalang Kabupaten Pemalang Provinsi Jawa Tengah
}

\author{
[Fisheries Resources Profile in Pemalang District Pemalang Regency, \\ Central Java]
}

\author{
Mauliddyane Zidhane, Tatty Yuniarti, Nayu Nurmalia \\ Program Studi Penyuluhan Perikanan Politeknik Ahli Usaha Perikanan \\ Jalan Cikaret Nomor 2 Bogor 16132, Jawa Barat
}

\begin{abstract}
Abstrak
Kecamatan Pemalang merupakan salah satu kecamatan di Kabupaten Pemalang sebagai sentra aktivitas perikanan. Potensi perikanan dapat dikembangkan dengan meningkatkan SDM sebagai motor penggerak bagi sektor perikanan. Tujuan penelitian adalah mengidentifikasi karakteristik, potensi perikanan, sistem produksi perikanan, sistem usaha perikanan dan sistem penyuluhan perikanan serta permasalahan perikanan di Kecamatan Pemalang. Penelitian dilaksanakan pada tanggal 1-30 Oktober 2019. Penentuan jumlah responden menggunakan rumus Slovin, pengambilan sampel secara Purposive Sampling dari populasi kelompok yang terdata pada Dinas Perikanan Kabupaten Pemalang. Pengambilan data melalui observasi dan wawancara menggunakan kuesioner. Data dianalisis menggunakan analisis deskriptif kualitatif. Analisis permasalahan perikanan menggunakan metode tree analysis. Hasil penelitian menunjukkan bahwa Kecamatan Pemalang memiliki potensi perikanan meliputi SDA berupa sungai, dan kolam. SDM perikanan sebanyak 172 orang tergabung dalam 15 kelompok perikanan, yaitu penangkapan (86 orang), budidaya (22 orang) dan pengolahan (64 orang). Komoditas tangkapan adalah udang dan cumi-cumi. Poklahsar mengolah olahan keripik kulit ikan, kerupuk ikan, pempek, pindang dan ikan asin. Komoditas budidaya adalah ikan bandeng. Nilai R/C usaha bidang perikanan rata-rata di atas 1. Hasil analisis masalah penangkapan: kurangnya pengendalian mutu hasil tangkapan. Permasalahan budidaya: produktivitas rendah karena belum mampu memberikan pakan sesuai kebutuhan ikan. Bidang pengolahan harga jual rendah dan belum menerapkan sanitasi dan higenitas. Rekomendasi penelitian yaitu perlunya: penanganan hasil tangkapan agar tidak terjadi kemunduran mutu ikan, penggunaan pakan alternatif untuk menghemat biaya produksi, perhitungan pemberian pakan, pembuatan produk inovasi olahan ikan dan demonstrasi cara sanitasi higenis. Kelembagaan penyuluhan perikanan dikelola oleh Dinas Perikanan Kabupaten Pemalang, dengan satu orang tenaga penyuluh perikanan di Kecamatan Pemalang.
\end{abstract}

Kata kunci: kelompok nelayan; poklahsar; sumberdaya perikanan

\section{Abstrack}

Pemalang Regency has qualified fisheries in the field of catching, aquaculture and processing. Fisheries potential can be developed by increasing the role of human resources that are the driving force for fisheries aspects. The aim of the practice of expertise is to identify the potential of fisheries, fisheries production system, fishery business system, fishery counseling system, and performance of fisheries group. The results of identification of fisheries areas are expected to be useful as a reference in determining extension activities through appropriate counseling actions. The practice of expertise was carried out from 1 to 30 October 2019. The research method used interviews and observation. Determination of the number of respondents obtained by the Slovin method. 35 respondents obtained. Primary data through observation and direct interviews with questionnaires. Data analysis uses descriptive qualitative analysis. Analysis of fisheries problems using tree analysis method. The results showed that Kecamatan Pemalang district has the potential for fisheries including natural resources in the form of rivers and ponds. The fisheries management resources include business people or $\mathrm{FHH}$ as many as 172 people who are members of 15 fisheries groups. The business sectors of the fisheries group include fishing (86 
people), aquaculture (22 people) and processing (64 people). Main commodity of catching field is endemic shrimp and squid. Poklahsar processes the catches to become processed varuious kind of refined fish products. The commodity of cultivation is milk fish. The average R / $\mathrm{C}$ value of the business field is above 1. Human Resources who have a business of catching as many as 86 people. In the field of Aquaculture with the potential for enlargement of milk fish, the results of the analysis of the catch problem are lack of quality control catching up. The problem of cultivation is low productivity and haven't been able to feed the fish properly. The processing sector has not yet applied sanitation and hygiene and has low-selling prices. Final practice recommendations are need for in control of the quality of the catch of fish for fisherman groups, the need to make alternative feeds for aquaqulture groups, and the improvement of hygienic sanitation for processing groups.

Keywords: fisheries resource; fisherman group; poklahsar

\section{Penulis korespondensi}

Mauliddyane Zidhane | mauliddyanez@gmail.com

\section{PENDAHULUAN}

Indonesia merupakan satu negara maritim yang memiliki kepulauan terbesar yang memiliki kondisi konstelasi geografis yang sangat strategis. Disamping itu, Indonesia memiliki 17.499 pulau, dengan luas perairan lautnya mencapai 5,9 juta $\mathrm{km}^{2}$ dan garis pantai sepanjang $\pm 81.000 \mathrm{~km}^{2}$. Kondisi tersebut menjadikan Indonesia sebagai center of gravity kawasan Asia Pasifik (Marsetio 2015).

Kabupaten Pemalang adalah sebuah wilayah kabupaten yang terdiri dari 14 Kecamatan dan 222 Desa/Kelurahan. Secara astronomis, Kabupaten pemalang terletak antara $80^{\circ}$ 52' 30" - 70²0' 11" Lintang Selatan (LS) dan antara 109 17 - 109 40' 30" Bujur Timur (BT). Berdasarkan posisi geografisnya, Kabupaten Pemalang memiliki batas-batas: Utara - Laut Jawa; Selatan - Kabupaten Purbalingga; Barat
- Kabupaten Tegal; dan sebelah Timur Kabupaten Pekalongan. Luas wilayah Kabupaten Pemalang adalah 111.530 Ha (BPS 2018).

Kajian identifikasi wilayah berguna untuk mengetahui keadaan sumber daya manusia, sumber daya alam dan sumber daya penunjang terutama pada wilayah pedesaan. Proses identifikasi wilayah perikanan ini sebagai bahan yang dapat dijadikan acuan dalam menentukan kegiatan penyuluhan melalui aksi penyuluhan yang tepat, untuk memperoleh data dan melibatkan masyarakat pelaku utama periakanan dalam proses dan kegiatan program di Kecamatan Pemalang dengan menggunakan metode wawancara dan observasi. Tujuan dari Penelitian adalah mengidentifikasi karakteristik dan potensi perikanan dan sistem produksi perikanan, sistem usaha perikanan, sistem penyuluhan perikanan dan kinerja 
kelompok perikanan, serta permasalahannya di Kecamatan Pemalang Kabapaten Pemalang Provinsi Jawa Tengah.

\section{BAHAN DAN METODE}

Penelitian dilaksanakan selama satu bulan pada tanggal 1 Oktober sampai dengan 30 Oktober 2019 yang bertempat di Kecamatan Pemalang Kabupaten Pemalang Provinsi Jawa Tengah.

Metode pengumpulan data melalui wawancara dan observasi. Alat yang digunakan untuk menggali data dalam kegiatan penelitian ini adalah kuesioner dan borang sebagai acuan dalam pengambilan data. Populasi dari kegiatan penelitian adalah seluruh pelaku usaha perikanan meliputi: pembudidaya, pengolah, nelayan serta pemasar di Kecamatan Pemalang Kabupaten Pemalang. Penentuan jumlah responden menggunakan rumus Slovin, pengambilan sampel secara Purposive Sampling dari populasi kelompok yang sudah terdata pada Dinas Perikanan Kabupaten Pemalang. Pelaku usaha perikanan yang tergabung dalam kelompok perikanan merupakan binaan penyuluh perikanan, yang berasal dari tiga desa potensi di Kecamatan Pemalang yaitu Kelurahan Bojongbata, Desa Lawangrejo dan Kelurahan Sugihwaras. Desa potensi tersebut didasarkan atas rekomendasi penyuluh perikanan di wilayah binaan Kecamatan Pemalang. Hasil identifikasi awal diketahui jumlah Rumah Tangga Perikanan (RTP) sebanyak 172 orang, yang terdiri atas 64 pengolah, 22 pembudidaya, dan 86 nelayan, dengan keseluruhannya sudah tergabung dalam kelompok perikanan. Data usaha perikanan diperoleh dari sampel pelaku usaha perikanan sebagai responden yang ditentukan dengan rumus slovin dengan galat (e) $15 \%$, yaitu sebanyak 35 responden.

Identifikasi potensi perikanan menggunakan metode analisis deskriptif. Metode analisis deskriptif ini untuk data kualitatif yang disajikan dalam bentuk uraian dan tabulasi sederhana seperti tabel, diagram, grafik sedangkan metode analisis statistik digunakan untuk data kuantitatif untuk mengukur mean, median, dan modus.

\section{HASIL DAN PEMBAHASAN}

Kecamatan Pemalang merupakan salah satu kecamatan yang berada di Kabupaten Pemalang Provinsi Jawa Tengah. Secara administratif batas wilayah Kecamatan Pemalang yaitu Laut Jawa di sebelah utara, Kecamatan Randudongkal dan Kecamatan Bantarbolang di sebelah selatan, Kabupaten Tegal di sebelah barat dan 


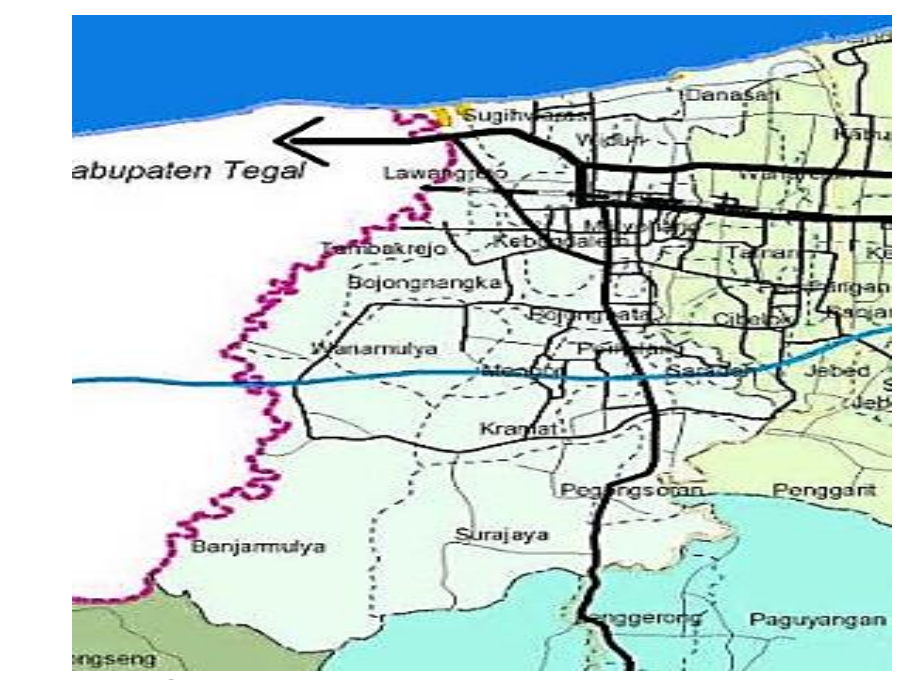

Sumber: https://orangpemalang.blogspot.com/ yang dimodifikasi

Kecamatan Taman di sebelah timur.

Peta Kecamatan Pemalang disajikan pada Gambar 1.

Batas wilayah ditandai dengan gapura dan patok. Jenis-jenis batas desa/kelurahan di darat dapat berupa batas alam atau batas buatan. Batas alam adalah unsur-unsur alami seperti gunung, sungai pantai, danau dan sebagainya, yang dinyatakan atau ditetapkan sebagai batas desa/kelurahan. Batas buatan adalah unsur-unsur buatan manusia seperti pilar batas, jalan, rel keretaapi, saluran irigasi dan sebagainya yang dinyatakan atau ditetapkan sebagai batas desa/kelurahan. Apabila batas wilayahnya adalah tampakan geomorfologi berarti garis batas ini terdiri dari watershed, sungai, dan alur terdalam (thalwegs) dari sungai besar (Handoyo 2011).
Kecamatan Pemalang terdiri dari 20 desa dan kelurahan, dimana setiap desa dipimpin oleh kepala desa dan kelurahan dipimpin oleh Kepala Kelurahan dengan jumlah Rukun Tetangga (RT) sebanyak 822 dan Rukun Warga (RW) sebanyak 184 yang terdiri dari Desa Banjarmulya, Desa Surajaya, Desa Pengongsoran, Desa Sungapan, Desa Paduraksa, Desa Kramat, Desa Wanamulya, Desa Mengori, Desa Sewaka, Desa Saradan, Kelurahan Bojongbata, Desa Bojongnangka, Desa Tambakrejo, Desa Kebondalem, Desa Mulyoharjo, Desa Pelutan, Desa Lawangrejo, Kelurahan Sugihwaras, Desa Widuri, dan Desa Danasari. Data luas desa/kelurahan di Kecamatan Pemalang Kabupaten Pemalang dapat dilihat dalam Gambar 2. 


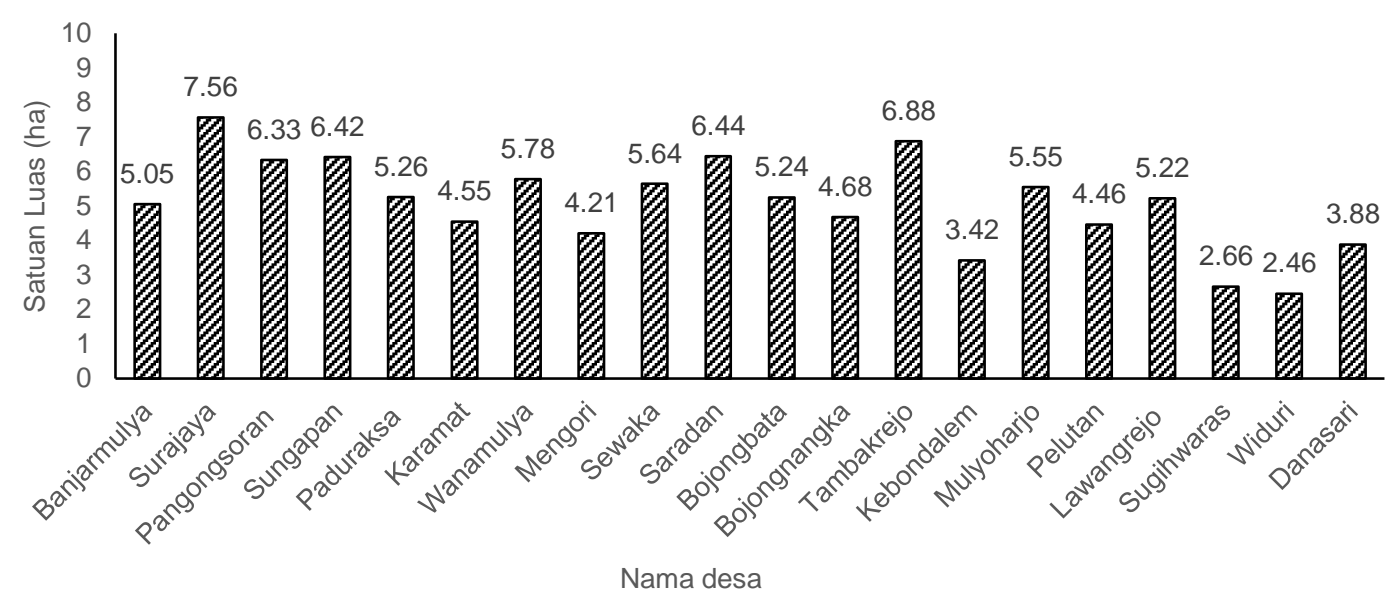

Gambar 2. Luas Desa di Kecamatan Pemalang Sumber BPS (2019)

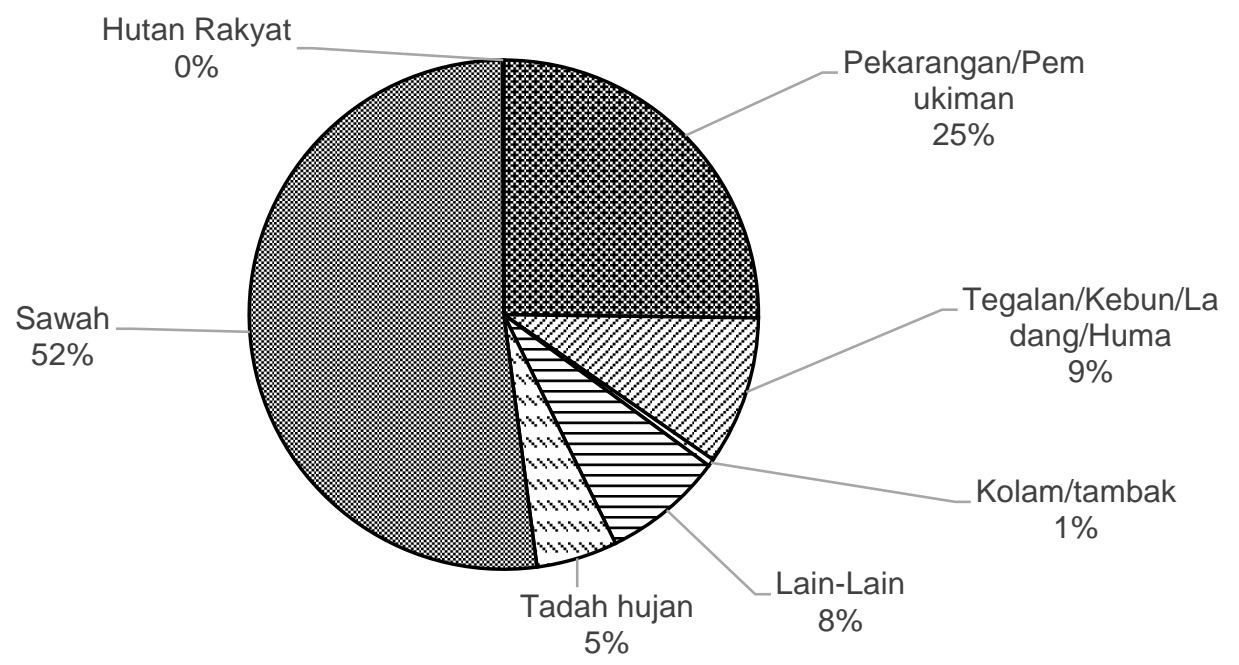

Gambar 3. Luas Wilayah Kecamatan Pemalang Menurut Penggunaan Lahan Sumber BPS (2019)

Berdasarkan Gambar 2, dapat dilihat luas desa terbesar adalah Desa Surajaya dan luas desa terkecil adalah Desa Widuri. Desa Surajaya memiliki luas desa yang besar karena desa ini merupakan kawasan desa wisata, salah satunya kawasan Wisata Pangeran
Purbaya. Luas wilayah tersebut terbagi dalam penggunaan lahan yang berbeda.

Berdasarkan Gambar 3, penggunaaan lahan paling besar di Kecamatan Pemalang yaitu lahan sawah dan pemukiman, sedangkan lahan untuk 
Tabel 1. Curah Hujan Kecamatan Pemalang

\begin{tabular}{llcc}
\hline No & Bulan & $\begin{array}{c}\text { Hari Hujan } \\
\text { (hari) }\end{array}$ & $\begin{array}{c}\text { Curah Hujan } \\
\text { (mm) }\end{array}$ \\
\hline 1 & Januari & 26 & 397 \\
2 & Februari & 18 & 310 \\
3 & Maret & 20 & 325 \\
4 & April & 13 & 95 \\
5 & Mei & 6 & 68 \\
6 & Juni & 8 & 46 \\
7 & Juli & 3 & 19 \\
8 & Agustus & 1 & 3 \\
9 & September & 5 & 93 \\
10 & Oktober & 7 & 99 \\
11 & Nopember & 12 & 217 \\
12 & Desember & 16 & 260 \\
\hline Rata-rata & $\mathbf{1 1 , 2 5}$ & $\mathbf{1 6 1}$ \\
\hline
\end{tabular}

kolam/ tambak masih sedikit. (Putuhena 2011). Data curah hujan di Karakteristik wilayah dengan penggunaan lahan sebagian besar untuk pemukiman biasanya termasuk dalam wilayah perkotaan. Pemanfaatan lahan untuk kolam atau tambak yang masih sedikit berhubungan dengan mata pencaharian penduduk setempat. Mata pencaharian utama masyarakat Kecamatan Pemalang adalah sebagai wiraswasta yaitu karyawan, pedagang dan nelayan.

Curah hujan memiliki banyak pengaruh terutama terhadap aktivitas penangkapan nelayan, selain itu tingkat curah hujan berperan karena dapat mempengaruhi aktifitas penangkapan dan kondisi peraian yang secara langsung serta berpengaruh pada keberadaan ikan perairan umum Kecamatan Pemalang dapat dilihat pada Tabel 1.

Keadaan iklim di Kecamatan Pemalang terutama jika dilihat dari jumlah curah hujan pada tahun 2017 menurun yakni dengan rata-rata hari hujan sebanyak 11,25 hari/bulan dan rata-rata curah hujan sebesar 161 $\mathrm{mm} /$ bulan. Jumlah curah hujan tertinggi terjadi pada bulan Januari dan Maret dan jumlah curah hujan terendah terjadi pada bulan Juli-September karena terjadinya musim kemarau. Pelaku utama perikanan (nelayan) di Kecamatan Pemalang tidak melaut pada saat musim hujan. Menurut Badan Meteorologi Klimatologi dan Geofisika (Kukuh Prasetyaningtyas 2020), terdapat empat kategori intensitas curah hujan di wilayah 


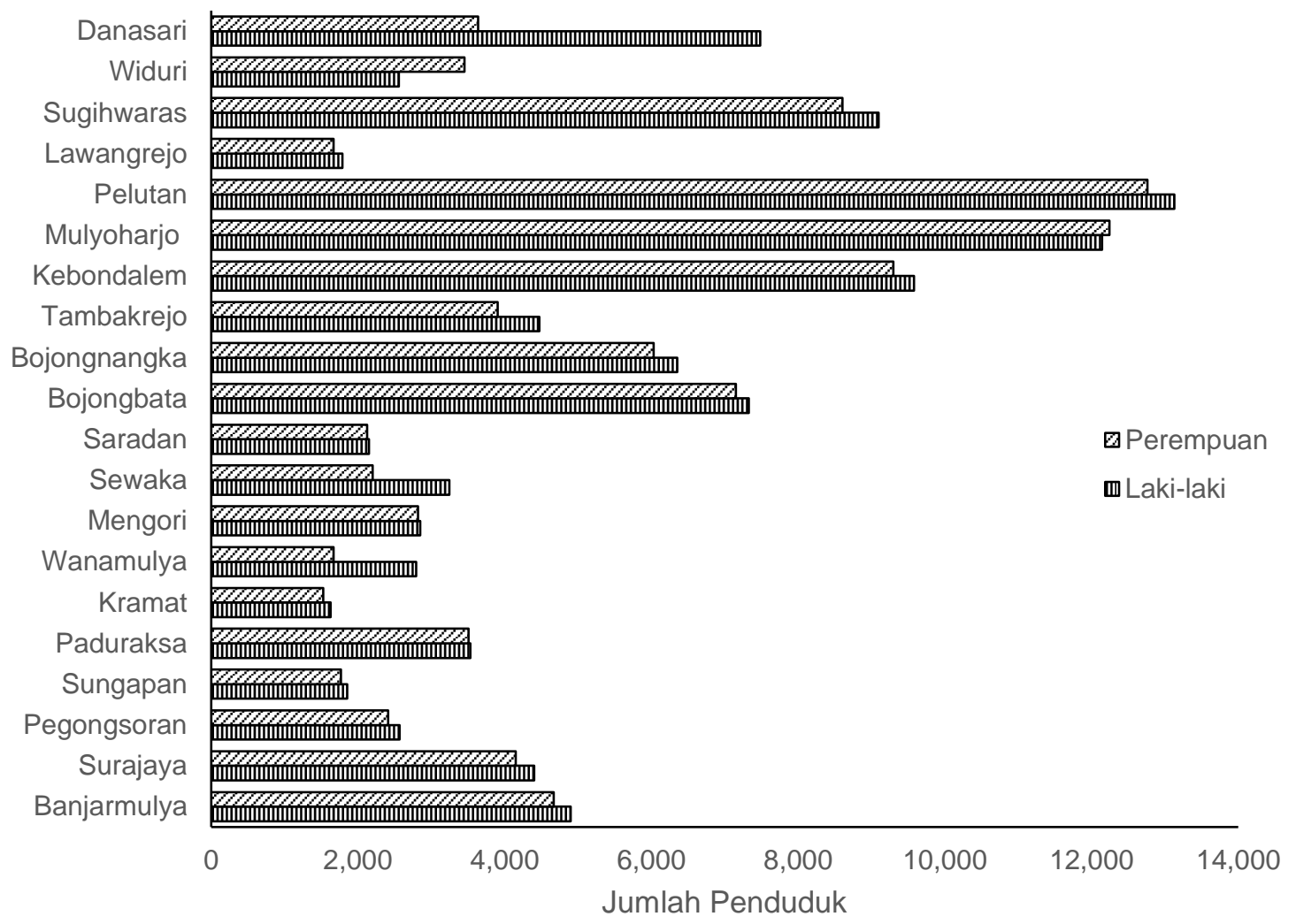

Gambar 4. Jumlah Penduduk Menurut Jenis Kelamin Sumber: BPS (2019)

Indonesia yaitu ringan (5-20 mm/hari), sedang (20-50 mm/hari), lebat (50-100 $\mathrm{mm} / \mathrm{hari})$ dan sangat lebat $(>100$ $\mathrm{mm} /$ hari). Berdasarkan kategori tersebut maka curah hujan di Kecamatan Pemalang termasuk dalam kategori ringan dengan intensitas curah hujan $14,3 \mathrm{~mm} /$ hari.

Kecamatan Pemalang mempunyai jumlah penduduk sebesar 198,640 jiwa, yang terdiri dari laki-laki 101,024 jiwa, dan perempuan sebanyak 97,616 jiwa.

Gambar 4 menunjukkan kepadatan penduduk terbesar terdapat di Desa Pelutan dengan jumlah total peduduk
25.895 jiwa diantaranya terdapat 13,131 jiwa penduduk laki-laki dan 12,764 jiwa penduduk perempuan. Sedangkan kepadatan penduduk terendah terdapat di Desa Kramat dengan jumlah penduduk total sebesar 3,156 jiwa diantaranya terdapat 1,629 jiwa penduduk laki-laki dan 1,527 jiwa penduduk perempuan. Kepadatan penduduk antara jumlah penduduk dengan luas wilayah yang dihuni (Ida 2017). 


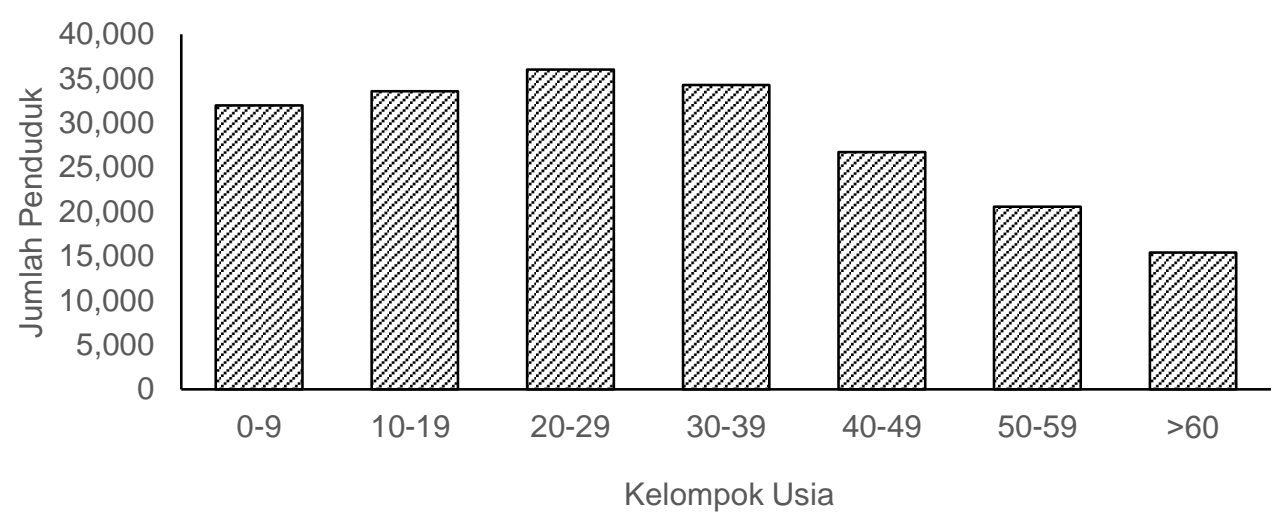

Gambar 5. Keadaan Penduduk Berdasarkan Kelompok Umur Sumber : BPS (2019)

Gambar 5 menunjukkan bahwa jumlah penduduk berdasarkan golongan umur terbanyak di Kecamatan Pemalang adalah penduduk dengan usia antara 2029 tahun, yaitu sebanyak 36,047 jiwa. Jumlah penduduk adalah potensi Sumber Daya Manusia (SDM) dalam pengembangan usaha perikanan maupun usaha non perikanan. Undangundang nomor 13 tahun 2003 Bab I Pasal 1 ayat 2 mengungkapkan bahwa batas usia kerja yang berlaku di Indonesia yaitu 15-64 tahun.

Kelembagaan pelaku utama perikanan di Kecamatan Pemalang yaitu Kelompok Pembudidaya ikan (POKDAKAN) terdiri dari 1 kelompok (Desa Lawangrejo dengan usaha pembesaran ikan bandeng), 9 kelompok KUB di (Kelurahan Sugihwaras). Kelompok pengolah dan pemasar (POKLAHSAR) di Kelurahan Sugihwaras terdiri dari 2 kelompok, 2 kelompok di Kelurahan Pelutan, 2 Kelompok di
Kelurahan Bojongbata, dan 1 kelompok di Desa Lawangrejo. Kelompok ini memproduksi berbagai macam olahan seperti pindang ikan, ikan asin, keripik kulit ikan nila, pempek ikan dan kerupuk ikan.

Kelompok usaha perikanan berpengaruh terhadap keberlanjutan dalam usaha perikanan yang dijalankan. Partisipasi anggota merupakan unsur utama dalam melaksanakan kegiatan kelompok dengan bersifat saling ketergantungan antar anggota (independent) (Hermawan, Amanah, dan Fatchiya 2017). 
Tabel 2. Kelompok Perikanan di Kecamatan Pemalang

\begin{tabular}{|c|c|c|c|c|}
\hline No & Nama Kelompok & Desa & $\begin{array}{c}\text { Jumlah } \\
\text { Anggota }\end{array}$ & Bidang Usaha Perikanan \\
\hline 1. & Muara Lancar & Lawangrejo & 30 & Pembesaran Ikan Bandeng \\
\hline 2. & Jaya Abadi & Lawangrejo & 10 & Pengolahan hasil perikanan \\
\hline 3. & Sejahtera Bersama & Bojongbata & 10 & Pengolahan hasil perikanan \\
\hline 4. & Wanita Gemari & Bojongbata & 10 & Pengolahan hasil perikanan \\
\hline 5. & Bina Karya Tama & Pelutan & 5 & Pengolahan hasil perikanan \\
\hline 6. & Mekar Jaya & Pelutan & 5 & Pengolahan hasil perikanan \\
\hline 7. & Melati & Sugihwaras & 5 & Pengolahan hasil perikanan \\
\hline 8. & Kusuma & Sugihwaras & 9 & Pengolahan hasil perikanan \\
\hline 9. & Arta Mina & Sugihwaras & 22 & Penangkapan Ikan \\
\hline 10. & Baru Rukun & Sugihwaras & 10 & Penangkapan Ikan \\
\hline 11. & Laut Banda & Sugihwaras & 10 & Penangkapan Ikan \\
\hline 12. & Mina Bangun & Sugihwaras & 10 & Penangkapan Ikan \\
\hline 13. & Mina Sentosa & Sugihwaras & 12 & Penangkapan Ikan \\
\hline 14. & Sabar Subur & Sugihwaras & 13 & Penangkapan Ikan \\
\hline 15. & Sejahtera Makmur & Sugihwaras & 11 & Penangkapan Ikan \\
\hline 16. & Tambah Mulya & Sugihwaras & 10 & Penangkapan Ikan \\
\hline 17. & Timbul Jaya & Sugihwaras & 10 & Penangkapan Ikan \\
\hline 18. & Mina Bahari & Danasari & 25 & Penangkapan Ikan \\
\hline 19. & Mina Jaya & Danasari & 16 & Penangkapan Ikan \\
\hline 20. & Mina Baru & Danasari & 16 & Penangkapan Ikan \\
\hline 21. & Penatas & Danasari & 16 & Penangkapan Ikan \\
\hline
\end{tabular}

Sumber: Laporan Penyuluh Perikanan Kecamatan Pemalang, 2018

Kelompok nelayan penangkapan ikan menangkap berbagai jenis ikan antara lain sebagian besar adalah udang dan cumi-cumi. Adapun kelompok tersebut secara rinci dapat dilihat pada Tabel 2.

Kegiatan budidaya Kecamatan Pemalang terdiri dari satu segmen usaha yaitu pembesaran Ikan Bandeng yang terdapat Desa Lawangrejo. Sebelum melakukan kegiatan produksi segmen usaha tersebut perlu dipersiapkan pasokan input berupa sarana produksi perikanan, tenaga kerja, serta modal. Pembesaran ikan yang di jalankan masih rendah produktivitasnya, hal ini disebabkan pembudidaya yang tidak memperhitungkan jumlah padat tebar dan hanya menggunakan estimasi. Keuntungan rata-rata yang di peroleh yaitu Rp. 2.169.571.- 


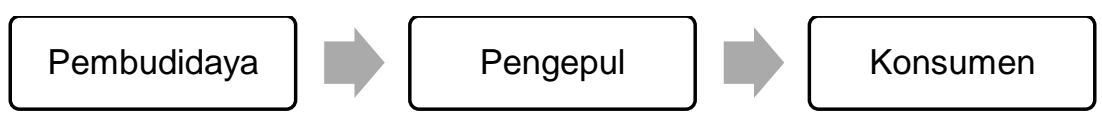

Gambar 6. Jalur Distribusi Pemasaran Kelompok Pembudidaya

Tabel 3. Tingkat Pemanfaatan Lahan Budidaya di Kecamatan Pemalang

\begin{tabular}{llcccccc}
\hline No & \multicolumn{1}{c}{ Nama } & $\begin{array}{c}\mathbf{A T} \\
\left(\mathbf{m}^{\mathbf{2}}\right)\end{array}$ & $\begin{array}{c}\mathbf{A O} \\
\left(\mathbf{m}^{\mathbf{2}}\right)\end{array}$ & $\begin{array}{c}\mathbf{N} \\
(\text { Siklus })\end{array}$ & $\begin{array}{c}\text { Si } \\
(\text { Hari) }\end{array}$ & $\begin{array}{c}\text { Nilai } \\
\text { LUI }\end{array}$ & Kriteria \\
\hline 1 & Ali Iskandar & 3.000 & 2.500 & 2 & 150 & 0,68 & Baik \\
2 & Untung Darsono & 3.250 & 3.000 & 3 & 90 & 0,67 & Baik \\
3 & Sukandar & 2.700 & 2.500 & 3 & 90 & 0,67 & Baik \\
4 & Sugianto & 2.250 & 2.000 & 3 & 90 & 0,64 & Baik \\
\hline Rata-rata & $\mathbf{2 . 8 0 0}$ & $\mathbf{2 . 5 0 0}$ & & & $\mathbf{0 , 6 6}$ & Baik \\
\hline
\end{tabular}

Berdasarkan kriteria nilai baku LUI (Land Utility Index) secara kuantitatif yaitu:

a. $\quad<0,4$ dikategorikan kurang,

b. $\quad 0,4-0,6$ dikategorikan cukup (madya) dan

c. $\quad>0,6$ di kategorikan baik.

Ikan bandeng yang telah dipanen dijual secara keseluruhan ke pengepul dengan cara menghubungi pengepul agar datang langsung mengambil hasil panen. Harga jual ikan dari pembudidaya kepada pengepul adalah sebesar $\mathrm{Rp}$. 18.000/kg. Harga jual pada pembudidaya masih dapat dikatakan rendah karena jika dibandingkan dengan pembudidaya ikan bandeng yang ada di Kabupaten Pemalang, kisaran harga jual ikan bandeng mencapai Rp. 24.000/kg. Harga jual yang rendah ini dipengaruhi oleh ukuran ikan bandeng yang relatif kecil dengan rata-rata size ikan bandeng 5-7 ekor/kg, sedangkan jika ukuran ikan bandeng dapat mencapai 4 ekor/kg dapat dijual dengan harga jual yang lebih tinggi. Jalur distribusinya adalah semi langsung yaitu dari produsen ke pedagang pengumpul, selanjutnya pedagang pengumpul menyalurkan ke konsumen (Mahyuddin 2010). Jalur distribusi pemasaran ikan disajikan pada Gambar 6.

Pemasaran merupakan salah satu dari kegiatan pokok yang harus dilakukan oleh seorang pengusaha untuk mempertahankan kelangsungan hidupnya, untuk mendapatkan laba, dan untuk berkembang. Berhasil atau tidaknya usaha tersebut sangat tergantung pada keahliannya dibidang pemasaran, produksi, keuangan, dan sumber daya manusia (Firdaus 2011). Pemasaran yang dilakukan oleh pembudidaya di Kecamatan Pemalang akan lebih efektif apabila hasil produksi 
dijual langsung kepada konsumen untuk memaksimalkan keuntungan tanpa perantara distributor ke penjual ikan.

Pemanfaatan lahan budidaya pada beberapa anggota kelompok pembudidaya pembesaran ikan bandeng KUB Muara Lancar di Kecamatan Pemalang sebagai responden dapat dilihat pada Tabel 3.

LUI menunjukkan bahwa tingkat pemanfaatan satuan lahan yang dilakukan RTP pembudidaya ikan. LUI dapat dijadikan dasar perbedaan dan perbandingan tingkat pemanfaatan suatu lahan antara hamparan untuk menunjang kegiatan penerapan teknologi dalam budidaya pembesaran ikan bandeng. Nilai LUI kurang dari 0.4 memberikan indikasi bahwa kemapuan pengadaan dan pengaturan air sehingga perlu adanya pengembangan (Praptokardyo 2008). Data pada Tabel 3 menunjukkan bahwa tingkat pemanfaatan lahan untuk budidaya di Kecamatan Pemalang ratarata berada di posisi 0.66 artinya pembudidaya dari responden kelompok Muara Lancar sudah dapat memanfaatkan lahan dengan baik. Luas lahan tidak seluruhnya dibuat untuk kolam, tetapi juga digunakan sebagai tempat penyimpanan pakan, akses jalan dan pematang di sekitar kolam, sehingga kolam tidak mudah bocor dan terkikis.

Pengolahan ikan yang dilakukan oleh kelompok pengolah di Kecamatan
Pemalang bervariasi yaitu olahan kerupuk kulit ikan, keripik kulit Ikan Nila, pindang ikan, dan ikan asin. Jenis produk olahan masih dominan dengan olahan sederhana, karena masih kurangnya kegiatan penyuluhan mengenai pengenalan produk-produk inovasi olahan berbahan dasar ikan. Produk inovasi seperti pembuatan bakso warnawarni dapat meningkatkan tingkat penerimaan konsumen terhadap ikan lele (Yuniarti, Yudistira, dan Suhrawardhan 2011).

Kegiatan pada sistem produksi pengolahan produk perikanan meliputi kegiatan penyediaan bahan baku, persiapan alat dan bahan, proses pengolahan, dan pengemasan. Keuntungan rata-rata yang diperoleh pengolah ikan sebesar Rp. 1,297,674.

Pemasaran produk olahan terbatas dan hanya sebagian kecil yang sudah memasarkan produknya ke luar kota ataupun menggunakan media sosial dalam pemasarannya. Pemasaran yang terbatas juga dipengaruhi faktor produk yang masih sederhana dalam pengemasannya, produk belum memiliki label dan merk. Sehingga harga jual produk rendah. Jalur distribusi produk hasil pengolahan kelompok pengolah dapat dilihat pada Gambar 7. 


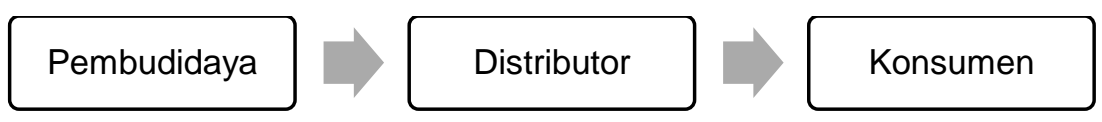

Gambar 7. Jalur Distribusi Pemasaran Kelompok Pengolah

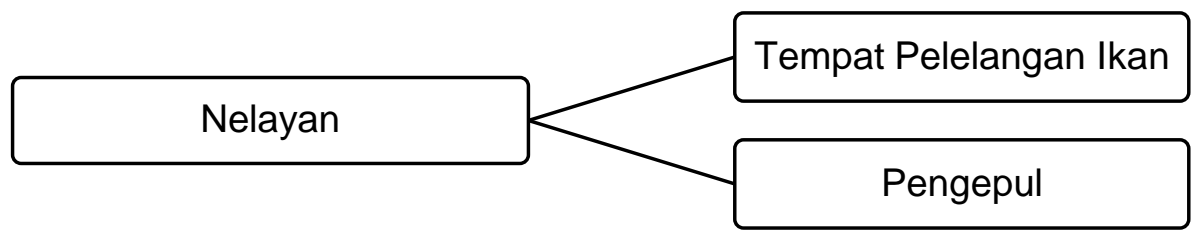

Gambar 8. Jalur Distribusi Pemasaran Kelompok Nelayan

Jalur pemasaran pada pengolahan hasil perikanan termasuk dalam jalur pemasaran semi langsung, karena pemasaran yang dilakukan pada kelompok pengolah dalam menyalurkan hasil produksinya terlebih dahulu ke tangan pedagang pengumpul, selanjutnya pedagang pengumpul menyalurkan ke konsumen (Mahyuddin 2010). Pemasaran ini sudah efektif, selain memasarkan produk melalui distributor, pengolah ikan juga menjual produk secara langsung ke konsumen, sehingga keuntungan yang diperoleh menjadi lebih tinggi karena tanpa perantara/distributor.

Hasil penangkapan ikan yang dilakukan oleh nelayan di Kecamatan Pemalang sebagian besar adalah udang dan cumi-cumi. Nelayan menangkap udang menggunakan alat tangkap Trammel Net. Nelayan menangkap cumicumi menggunakan jaring dan alat tangkap bantu berupa lampu dengan sumber tenaga generator listrik untuk menarik perhatian ikan. Hasil tangkapan disimpan di dalam cool box ataupun fiber dengan es balok agar ikan tidak membusuk.

Kelompok nelayan di Kecamatan Pemalang sebagian besar menjual hasil tangkapnya ke Tempat Pelelangan Ikan (TPI), karena jika melalui TPI harga jual udang ataupun cumi-cumi jauh lebih tinggi jika dibandingkan dengan harga di pengepul. Harga udang di TPI Tanjung Sari adalah Rp. 70,000/kg dan harga cumi-cumi Rp. 45,000/kg, sedangkan harga pada pengepul adalah $\mathrm{Rp}$. $60,000 / \mathrm{kg}$ udang dan Rp. 35,000/kg.

Layanan pendukung yang mendukung kegiatan usaha pelaku utama perikanan di Kecamatan Pemalang adalah lembaga pemerintah, lembaga pembiayaan, dan lembaga penyuluhan. Lembaga pemerintah yaitu Dinas Perikanan Kabupaten Pemalang yang telah memberikan bantuan kepada pembudidaya berupa benih, kepada pengolah berupa alat produksi dan 
Tabel 4. Analisa usaha kelompok pembudidaya, penangkap dan pengolah ikan

\begin{tabular}{|c|c|c|c|}
\hline Substansi & Budidaya/Siklus & $\begin{array}{c}\text { Penangkapan (3 } \\
\text { Day Fishing) / } \\
\text { thn }\end{array}$ & $\begin{array}{c}\text { Pengolahan / } \\
\text { bln }\end{array}$ \\
\hline Biaya Investasi & Rp. $39,955,000$ & Rp, 173,684,375 & Rp. $10,545,846$ \\
\hline Total biaya Produksi & Rp. 2,982,929 & Rp. $6,684,429$ & Rp. 4,633,096 \\
\hline Biaya tetap & Rp. 417,929 & Rp. 653,429 & Rp. 971,327 \\
\hline Biaya variable & Rp. $2,565,000$ & Rp. 6,031,000 & Rp. 3,661,769 \\
\hline Pendapatan & Rp. 5,152,500 & Rp. 9,879,688 & Rp. 5,930,550 \\
\hline Keuntungan & Rp. $2,169,571$ & Rp. $3,195,259$ & Rp. $1,297,674$ \\
\hline BEP (rupiah) & Rp. 816,676 & Rp. $1,756,277$ & Rp. 2,422,741 \\
\hline BEP (unit) & $45 \mathrm{~kg}$ & $32 \mathrm{~kg}$ & 252 unit \\
\hline $\mathrm{R} / \mathrm{C}$ & 1,7 & 1.5 & 1.4 \\
\hline ROI & $72.2 \%$ & $47.3 \%$ & $36.6 \%$ \\
\hline PP & 5.3 tahun & 5.3 tahun & 0.9 tahun \\
\hline
\end{tabular}

kepada nelayan berupa alat tangkap. Lembaga pembiayaan yaitu bank telah memberikan kredit kepada pelaku utama perikanan. Lembaga penyuluhan perikanan yaitu Dinas Perikanan Kabupaten Pemalang memiliki peran strategis memberikan kontribusi berupa materi maupun non materi, seperti kegiatan pelatihan, maupun diklat dan penyuluhan.

Keberhasilan usaha perikanan dapat dilihat dari hasil analisis usaha kegiatan perikanan yang dilakukan. Hasil analisis usaha yang dihitung dalam jangka waktu setahun dari tiga segmen usaha perikanan (pembesaran, penangkapan dan pengolahan) dapat dilihat pada Tabel 4.

Berdasarkan Tabel 4 Rata-rata analisis usaha yang diddapatkan dengan
R/C diatas 1. Usaha yang dilakukan sudah layak dari segi ekonomois. Potensi perikanan yang ada di Kecamatan Pemalang sangat mendukung untuk dikembangkan.

Penyuluhan dapat memberi kontribusi pada peningkatan kemampuan nelayan. Melalui penyuluhan, akan terjadi perubahan pengetahuan, keterampilan, dan sikap nelayan. Bisnis pelaku usaha perikanan akan berkembang, demikian pula lingkungan hidup dan sosial budaya masyarakat setempat (Amanah 2006). Sistem penyuluhan perikanan merupakan tahapan - tahapan maupun komponen - komponen yang harus terdapat dalam suatu kegiatan penyuluhan, diantaranya: kelembagaan penyuluhan yang terdapat 
Tabel 5. Rekapitulasi PenilaianFungsi Kelompok

\begin{tabular}{llcccc}
\hline No & \multicolumn{1}{c}{ Fungsi } & $\begin{array}{c}\text { Muara } \\
\text { Lancar }\end{array}$ & $\begin{array}{c}\text { Melati } \\
\text { Sejati }\end{array}$ & $\begin{array}{c}\text { Baru } \\
\text { Rukun }\end{array}$ & $\begin{array}{c}\text { Rata- } \\
\text { rata }\end{array}$ \\
\hline 1 & Sebagai wahana belajar & 2 & 3 & 2.3 & 2.4 \\
2 & Sebagai wahana kerjasama & 1.7 & 2.7 & 2.7 & 2.4 \\
3 & Sebagai unit produksi & 2 & 2.3 & 2 & 2.1 \\
4 & Sebagai unit usaha atau bisnis & 1.8 & 2.3 & 2.3 & 2.1 \\
5 & Sebagai kesatuan swadaya swadana & 2.2 & 3 & 2.2 & 2.5 \\
6 & Sebagai unit penyedia sarana prasarana produksi & 1.7 & 2.5 & 1.5 & 1.9 \\
7 & Sebagai unit pengolahan dan pemasaran & 2.3 & 3 & 2.3 & 2.5 \\
8 & Sebagai unit jasa penunjang & 1.5 & 2 & 1 & 1.5 \\
\hline
\end{tabular}

di Kecamatan Pemalang dikelola langsung oleh Dinas Perikanan Kabupaten Pemalang. Penyusunan programa dilakukan oleh tim penyuluh setiap kecamatan yang kemudian langsung di berikan kepada Dinas Perikanan Kabupaten Pemalang. (2) ketenagaan penyuluhan perikanan di Kecamatan Pemalang terdiri dari satu orang Penyuluh Perikanan Bantu (PBB) yaitu Dian Apriani, S.St.Pi, dengan wilayah binaan Kecamatan Pemalang.

Sasaran penyuluhan perikanan adalah pelaku utama dan pelaku usaha yang ada di Kecamatan Pemalang. Kegiatan penyuluhan perikanan yang dilakukan sesuai dengan kebutuhan dari pelaku utama itu sendiri pada bidang budidaya perikanan, pengolahan hasil perikanan, dan penangkapan ikan.

Hasil penilaian fungsi kelompok pada tiga kelompok sampel yaitu Pokdakan Muara Lancar, Poklahsar Melati Sejati, dan KUB Baru Rukun dengan rata-rata nilai yaitu 2,2. Hasil rata-rata nilai fungsi kelompok perikanan tersebut termasuk pada kategori cukup (1,8 - 2,5). Rekapitulasi penilaian fungsi kelompok yang dilakukan pada tiga kelompok sampel terdapat dalam Tabel 5.

Data pada Tabel 5 menunjukkan bahwa penilaian fungsi kelompok perikanan pada kelompok sampel diperoleh dengan nilai tertinggi adalah pada fungsi kelompok sebagai unit pengolahan dan pemasaran. Hal tersebut karena pada kelompok perikanan di Kecamatan Pemalang sebagian besar memilih bergabung dalam kelompok perikanan untuk kegiatan pengolahan dan pemasaran baik perikanan tangkap, pengolahan hasil perikanan, maupun budidaya ikan. Dengan bergabungnya dalam kelompok akan lebih mudah dalam mencapai produksi dan produktivitas yang diinginkan dan dengan adanya kelompok 


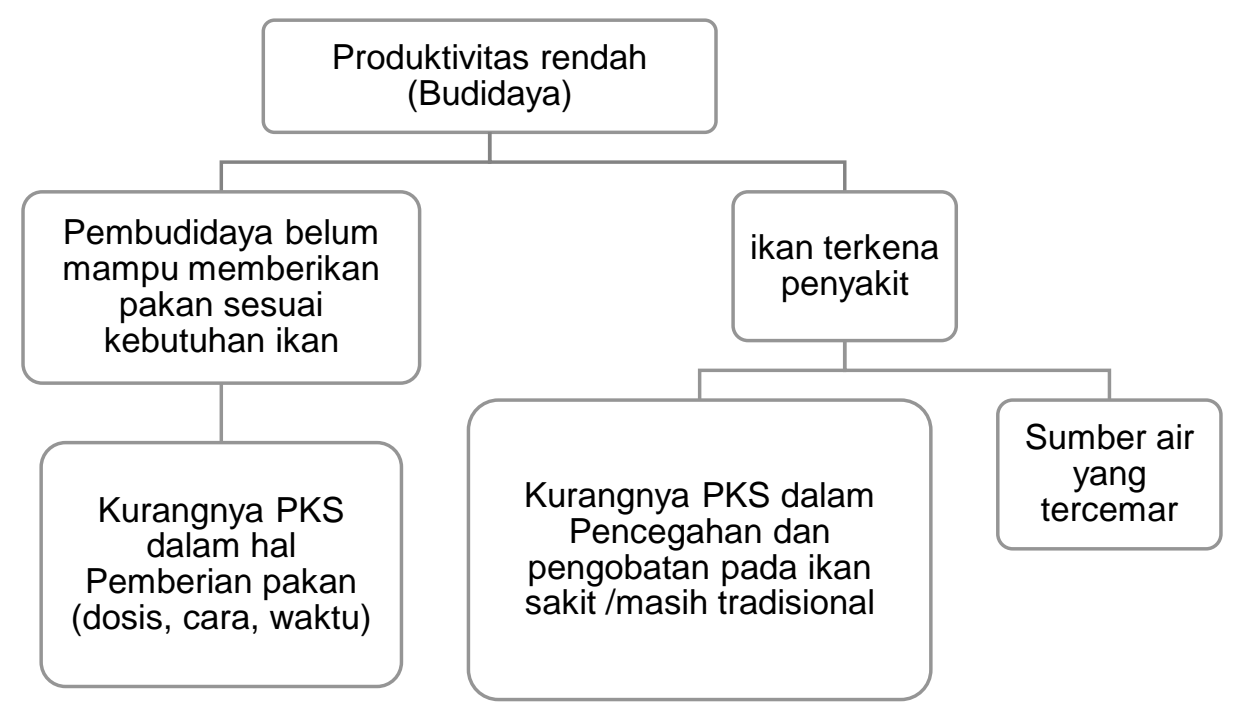

Gambar 9. Pohon masalah aspek teknis kelompok pembudidaya

akan memberikan kemudahan akses pemasaran melalui pengenalan produkproduk hasil produksi melalui penyuluh perikanan, seperti kegiatan pameran atau perlombaan. Fungsi kelompok penting sebagai kelas belajar, wahana kerjasama, dan unit produksi yang mampu meningkatkan partisipasi pelaku usaha pada proses produksi (Ramadoan, Muljono, dan Pulungan 2013).

Fungsi kelompok dengan nilai terendah adalah kelompok sebagai unit jasa penunjang. Hal ini disebabkan beberapa kelompok - kelompok yang kurang aktif dalam kegiatan yang dilakukan oleh penyuluh perikanan, sehingga masih kurang dalam kerjasama serta pembinaan dari penyuluh perikanan. Oleh karena itu perlu ditingkatkan pembinaan yang lebih intens pada kelompok-kelompok yang kurang aktif sehingga setiap fungsi kelompok dapat tercapai dengan baik.

Aksi penyuluhan yang tepat guna dan tepat sasaran terhadap pelaku utama dan atau pelaku usaha memerlukan penetapan analisa permasalahan perikanan. Analisis masalah yang digunakan yaitu dengan metode Tree Analysis yang disajikan pada Gambar 9.

Rendahnya produktivitas tambak disebabkan oleh rendahnya keberhasilan hidup (survival rate) dan pertumbuhan (growth rate) serta ketidakstabilan produksi, yang diduga disebabkan karena penurunan kualitas lingkungan sebagai akibat mewabahnya penyakit, kesalahan manajemen lingkungan perairan dan penerapan teknoligi budidaya (Asaf, Athirah, dan Ratnawati 2013). Masalah umum pada pembudidaya adalah produktivitas 


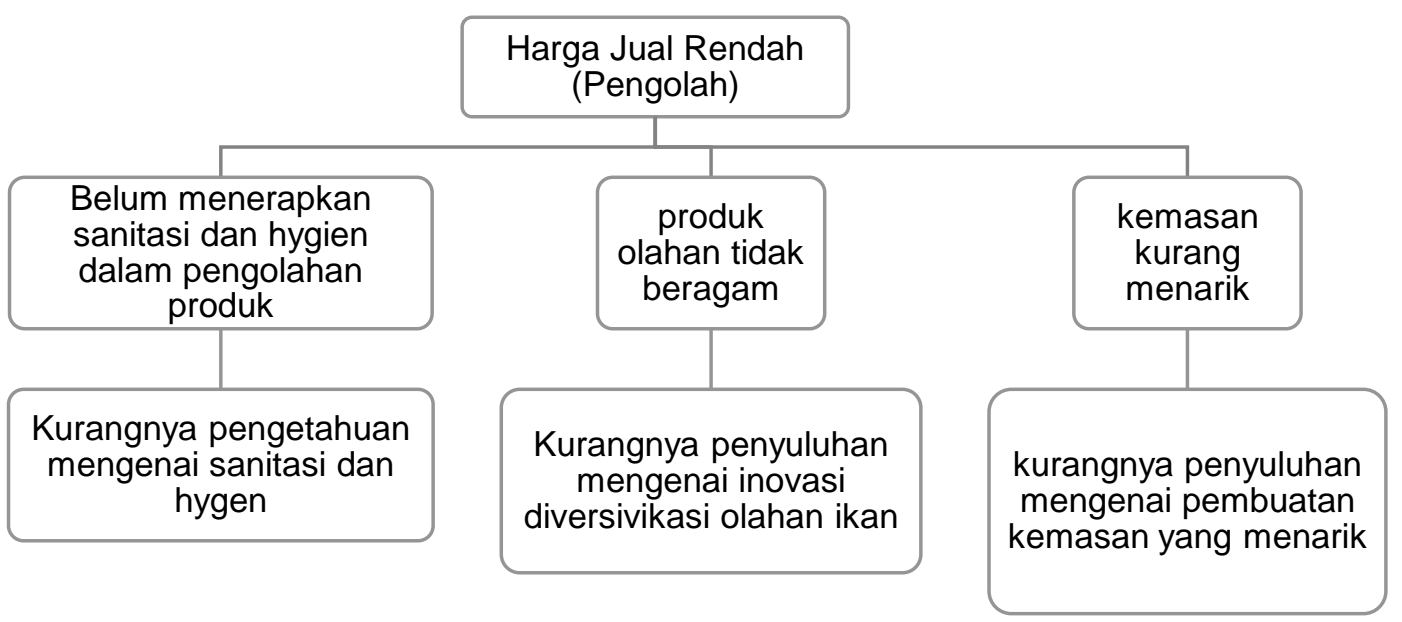

Gambar 10. Pohon masalah aspek teknis kelompok pengolah

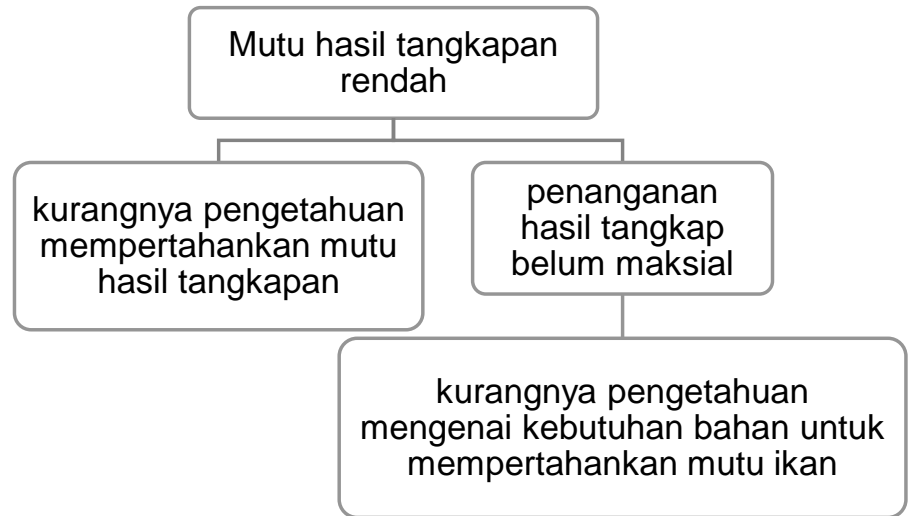

Gambar 11. Pohon masalah aspek teknis kelompok penangkapan

rendah yang disebabkan karena

pembudidaya belum mampu

memberikan pakan sesuai kebutuhan ikan, dan ikan terkena penyakit. Hal ini disebabkan karena kurangnya pengetahuan, keterampilan dan sikap (PKS) dalam hal pemberian pakan (dosis, cara dan waktu), kurangnya PKS dalam pencegahan dan pengobatan pada ikan sakit serta faktor utama yang menyebabkan ikan terkena penyakit adalah sumber air di sekitar kolam yang tercemar.
Berdasarkan pohon masalah pada Gambar 10, yang menjadi masalah umum pada kelompok pengolah adalah harga jual produk pengolah yang masih rendah yang terjadi karena kemasan yang kurang menarik yang disebabkan karena kurangnya penyuluhan mengenai pembuatan kemasan yang menarik, produk olahan yang kurang beragam disebabkan kurangnya penyuluhan mengenai diversifikasi olahan hasil perikanan.Selain itu pengolah juga belum menerapkan sanitasi dan hygiene 


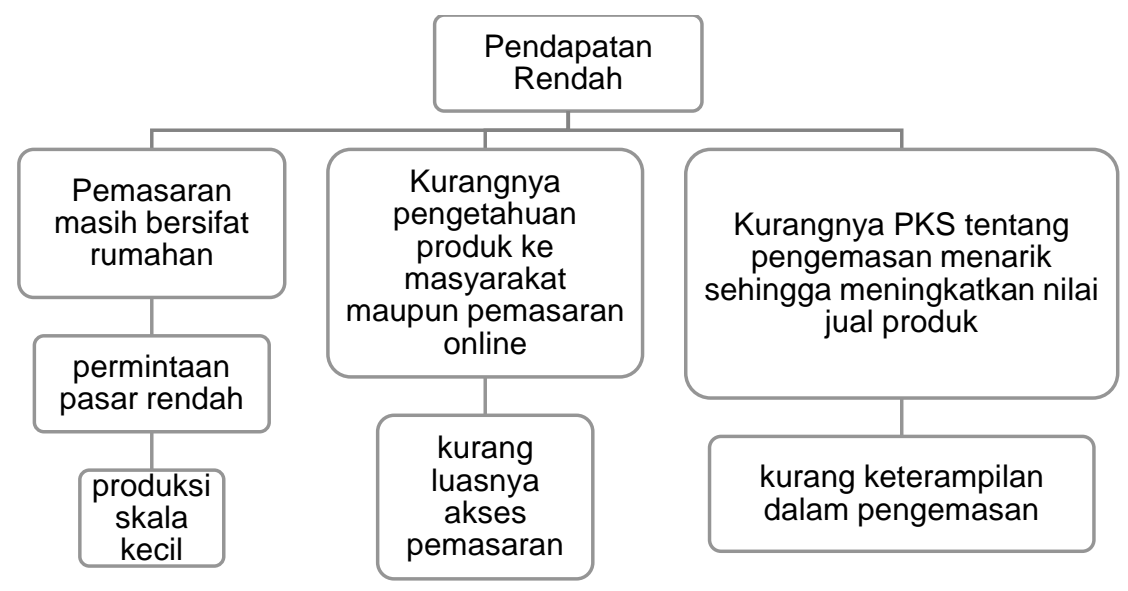

Gambar 12. Pohon masalah aspek ekonomi

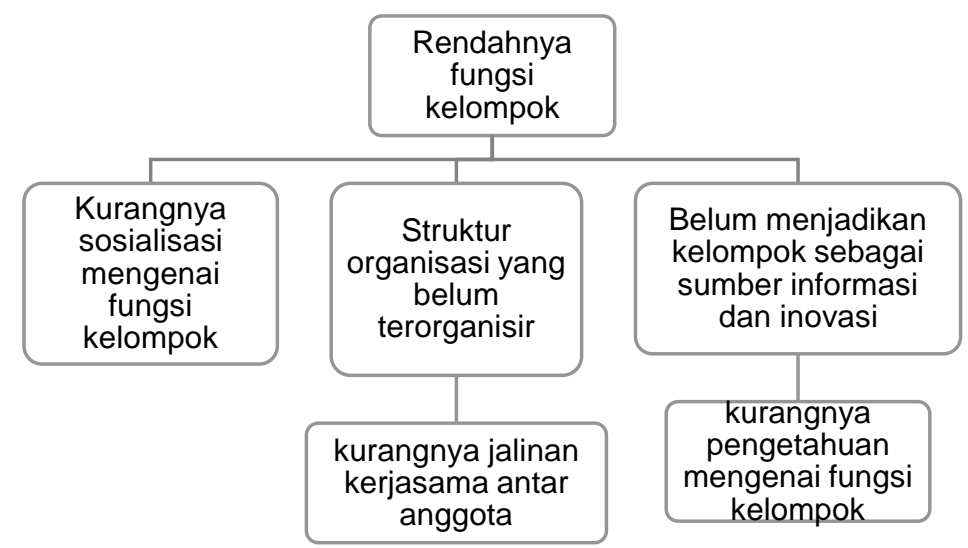

Gambar 13. Pohon masalah aspek sosial

dalam proses produksi yang produksi, penyimpanan, pengangkutan, berpengaruh penting terhadap produk dan/atau peredaran pangan wajib: a. olahan, karena untuk mendapatkan Memenuhi persyaratan sanitasi; dan b. legalitas, produk yang dihasilkan harus Menjamin keamanan pangan dan/atau mempunyai kualitas yang baik dengan proses produksi yang bersih dan sehat keselamatan manusia.

Salah satu faktor yang menentukan dengan menerapkan prinsip sanitasi dan hygiene.

Undang undang No. 18 tahun 2012 tentang Pangan pasal 71 ayat (2) nilai jual ikan dan hasil perikanan lain adalah tingkat kesegarannya (Junianto 2003). Mutu kesegaran dapat mencakup rupa, atau kenampakan, rasa, bau, dan menyatakan bahwa setiap orang yang juga tekstur yang secara sadar ataupun menyelenggarakan kegiatan atau proses tidak sadar akan dinilai oleh pembeli atau pengguna dari produk tersebut (Agustini 
2003). Baerdasarkan Gambar 11, masalah umum pada kelompok nelayan adalah mutu hasil tangkapan yang rendah disebabkan oleh kurangnya pengetahuan nelayan dalam mempertahankan mutu hasil tangkapan dan kurangnya penyuluhan mengenai hasil tangkap, sehingga perlu adanya kegiatan penyuluhan untuk meningkatkan PKS nelayan mengenai cara mempertahankan mutu hasil tangkapan.

Masalah umum pada pohon masalah aspek ekonomi yang disajikan dalam Gambar 12 adalah pelaku utama kurang mengetahui aspek pasar. Hal ini dapat disebabkan karena kegiatan usaha yang masih bersifat rumahan sehingga jangkauan pasarnya rendah, selain itu kurangnya sosialisasi produk ke masyarakat maupun secara online dan kurangnya PKS tentang pengemasan menarik sehingga meningkatkan nilai jual produk juga menjadi penyebab masalah umum tejadi.

Daya tarik suatu produk tidak dapat terlepas dari kemasannya. Kemasan merupakan pemicu yang dapat mempengaruhi konsumen untuk memberikan respon positif, dalam hal ini membeli produk. Karena tujuan akhir pengemasan adalah penjualan. Kemasan merupakan suatu cara untuk meningkatkan laba perusahaan. Oleh karena itu, kemasan harus dibuat dengan semenarik mungkin. Dengan kemasan yang menarik diharapkan dapat memikat dan menarik perhatian konsumen. Selain itu kemasan juga dapat mengurangi kerusakan barang dan memberikan kemudahan dalam proses pengiriman (Cenadi 2000).

Berdasarkan Gambar 13, masalah umum dalam aspek sosial adalah kurangnya pembinaan kelompok yang disebabkan oleh kurangnya sosialisasi mengenai fungsi kelompok, struktur organisasi yang belum terorganisir, dan belum menjadikan kelompok sebagai sumber informasi dan inovasi. Keberhasilan kelompok sebagai unit belajar dipengaruhi oleh faktor sikap terhadap profesinya, interaksi anggota kelompok, dan penyuluh, sedangkan keberhasilan kelompok sebagai unit kerja sama dipengaruhi oleh faktor interaksi antar anggota, norma kelompok, penyuluh, dan pembinaan pamong desa. Keberhasilan kelompok sebagai unit produksi produksi dipengaruhi oleh faktor self efficacy (keyakinan mampu berhasil), interaksi anggota dan gaya kepemimpinan ketua kelompok. Meningkatnya kerjasama dalam kelompok (pengadaan saprokan, pemasaran, pengolahan) berpengaruuh dalam meningkatkan produksi (Hariadi 2011).

Berdasarkan hasil dan pembahasan kegiatan di atas maka 
rekomendasi kegiatan adalah sebagai berikut:

a. Melakukan kegiatan penyuluhan tentang pengembangan Kelompok Budidaya Perikanan (POKDAKAN) dengan materi tentang fungsi kelompok.

b. Sosialisasi cara pencegahan penyakit pada ikan dan pelatihan penanganan ikan yang terkena penyakit kepada kelompok pembudidaya.

c. Pelatihan penggunaan pakan alternatif untuk menghemat biaya produksi dan cara perhitungan pemberian pakan kepada kelompok pembudidaya.

d. Pelatihan terhadap kelompok pengolah mengenai pembuatan produk-produk inovasi berbahan baku ikan dan demonstrasi cara menerapkan sanitasi dan hygen dalam proses produksinya.

e. Pelatihan pada kelompok pengolah mengenai pembuatan kemasan produk agar menjadi nilai tambah pada penjualan produk. Serta sosialisasi mengenai cara pemasaran secara online.

f. Sosialisasi terhadap kelompok nelayan mengenai cara penanganan pada hasil tangkapan agar tidak terjadi kemunduran mutu ikan yang menyebabkan harga jual yang rendah.
Sasaran yang dituju berdasarkan hasil observasi adalah kelompok yang benar-benar melakukan proses produksi baik pembudidaya, pengolah, maupun nelayan. Pembudidaya yang hanya sebagai sampingan ataupun yang belum melakukan proses budidaya tetapi mempunyai lahan juga merupakan sasaran. Sasaran yang harus diutamakan yaitu kelompok-kelompok yang telah berjalan, yang akan memancing yang lain untuk melakukan usaha perikanan.

Narasumber/fasilitator adalah penyuluh perikanan Kecamatan Pemalang. Penyuluh ini dapat berperan menjadi narasumber apabila diperlukan diskusi dengan sasaran tentang permasalahan yang ditemukan olehsasaran. Penyuluh dapat memberi solusi dari permasalahan yang dihadapi. Apabila penyuluh tidak dapat memecahkan masalah dan memberikan solusi, penyuluh bisa sebagai fasilitator menghubungkan sasaran dengan pihak terkait dalam hal ini bisa pegawai yang ada di bidang perikanan. Penyuluh juga dapat menghubungkan pembudidaya dengan Dinas Perikanan Kabupaten Pemalang untuk pengajuan pengembangan kelompok.

Media yang tepat berdasarkan hasil observasi dilapangan adalah media tertayang dan media tercetak. Media tercetak ini bisa berupa folder, dan 
leaflet, sedangkan media tertayang ini bisa berupa tanyangan slide (powerpoint) melalui proyektor atau infocus atau juga penayangan film perikanan. Media ini dirasa efektif dan pembudidaya akan lebih cepat memahami materi penyuluhan apabila digunakan media tertayang dan media tercetak.

Metode yang tepat berdasarkan hasil observasi dilapangan adalah metoda pertemuan kelompok, demcar, dempond, ceramah, anjangsana dan diskusi kelompok. Metode-metode ini dirasa sangat efektif karena pembudidaya dapat berperan aktif dalam peningkatan kesejahteraan pelaku utama dan pelaku usaha perikanan.

\section{SIMPULAN DAN SARAN}

\section{Simpulan}

Berdasarkan hasil analisis terhadap data sekunder maupun primer yang diperoleh saat penelitian di Kecamatan Pemalang Kabupaten Pemalang, maka dapat disimpulkan halhal berikut:

1. Kondisi wilayah di Kecamatan Pemalang kondusif untuk pengembangan kegiatan perikanan karena kondisi potensi sumber daya alam dan sumber daya manusia yang ada mendukung pengembangan perikanan. Potensi sumberdaya perikanan adalah adanya sungai dan kolam di Kecamatan Pemalang.

2. Wilayah Kecamatan Pemalang terbagi atas 20 desa/kelurahan dengan mempunyai penduduk sebesar 198.640 jiwa. RTP yang terdapat di Kecamatan Pemalang sebesar 172 , diantaranya 86 orang nelayan, 22 orang pembudidaya, dan 64 orang pengolah hasil perikanan. Kelompok perikanan dapat dikatakan layak berdasarkan nilai kelayakan usaha R/C Ratio lebih dari 1.Tingkat pemanfaatan lahan untuk budidaya termasuk dalam kategori baik dengan hasil perhitungan LUI rata-rata sebesar 0,66 .

3. Hasil analisis masalah dari 35 responden di Kecamatan Pemalang yaitu permasalahan pada sistem produksi perikanan mayoritas menggunakan sistem teknologi budidaya tradisional. Permasalahan pada kelompok pengolah adalah kurangnya diversifikasi olahan produk dan kurangnya penerapan sanitasi dan hygiene Permasalahan pada perikanan tangkap adalah nelayan yang masih kurang dalam mempertahankan mutu hasil tangkapan.

4. Sistem penyuluhan terdapat ketenagaan penyuluhan yaitu satu orang penyuluh perikanan. 
Kelembagaan penyuluhan perikanan di bawah tanggung jawab Dinas Perikanan Kabupaten Pemalang. Sasaran penyluhan yaitu kelompok perikanan (pembudidaya, nelayan dan pengolah ikan). Sarana dan prasarana penunjang kegiatan penyuluhan, penyelenggaraan perikanan dan pembiayaan penyuluhan berasal dari dana APBN.

\section{Saran}

1. Perlu diadakannya penyuluhan untuk menumbuhkembangkan potensi perikanan yang ada.

2. Perlu diadakannnya kegiatan penyuluhan perikanan yang berjalan dengan baik sehingga penyampaian materi atau informasi dari penyuluh cepat serta permasalahanpermasalahan yang dihadapi pelaku utama akan cepat terselesaikan dengan adanya penyuluhan perikanan.

3. Perlu dikembangkan terobosan teknologi yang mendukung keberhasilan budidaya. Sehingga usaha perikanan dapat menghasilkan keuntungan yang optimal.

\section{DAFTAR PUSTAKA}

Agustini, Tri Winarni. 2003. Uji Mutu Terpadu pada Beberapa Spesies
Ikan dan Produk Perikanan di Indonesia. Laporan Akhir Hibah Bersaing XI Perguruan Tinggi. Semarang (ID).

Amanah, Siti. 2006. "PENYULUHAN PERIKANAN." Jurnal Penyuluhan 2(4). doi: 10.25015/penyuluhan.v2i4.2117.

Asaf, Ruzkiah, Admi Athirah, dan Erna Ratnawati. $2013 . \quad$ "Faktor Pengelolaan Tambak yang Mempengaruhi Produktivitas Tambak di Kabupaten Indramayu Provinsi Jawa Barat." in Prosiding Forum Inovasi Teknologi Akuakultur 2013. Maros (ID): Balai Penelitian Perikanan Budidaya Air Payau.

BPS. 2018. Kabupaten Pemalang dalam angka 2018. Pemalang.

BPS. 2019. Kecamatan Taman dalam Angka. Pemalang (ID): BPS Kabupaten Pemalang.

Cenadi, Christine Suharto. 2000. "Peranan Desain Kemasan Dalam Dunia Pemasaran." Nirmana 2(2):92-103.

Firdaus, M. 2011. Manajemen Agribisnis. Jakarta: PT. Bumi Aksara.

Handoyo, Sri. 2011. "Geospatial Aspect of the Land Border Between Indonesia and Timor-Leste." Majalah IImiah Globe 13(2):175-83. Hariadi, Sunarru Samsi. 2011. Dinamika kelompok: teori dan aplikasinya 
untuk analisis keberhasilan kelompok tani sebagai unit belajar, kerjasama, produksi, dan bisnis. Sekolah Pascasarjana, Universitas Gadjah Mada.

Hermawan, Aan, Siti Amanah, dan Anna Fatchiya. 2017. "Partisipasi Pembudidaya Ikan dalam Kelompok Usaha Akuakultur di Kabupaten Tasikmalaya." Jurnal Penyuluhan 13(1):1. doi:

10.25015/penyuluhan.v13i1.12903.

Ida, Mantra Bagoes. 2017. Geografi 2 SMA kelas XI. diedit oleh Quandra. Jakarta.

Junianto. 2003. Teknik Penanganan Ikan. Jakarta (ID): Penebar Swadaya.

Kukuh Prasetyaningtyas. 2020. "Analisis Curah Hujan dan Sifat Hujan Bulan Desember 2019." Diambil 2 Februari 2020

(https://www.bmkg.go.id/berita/?p= analisis-curah-hujan-dan-sifathujan-bulan-desember2019\&lang=ID\&tag=klimatologi).

Mahyuddin, Kholis. 2010. Panduan Lengkap Agribisnis Lele. Jakarta (ID): Penebar Swadaya.

Marsetio. 2015. "Aktualisasi Peran
Pengawasan Wilayah Laut."

Praptokardyo, K. dan W. 2008.

Pengembangan

Perikanan

Budidaya. Bogor: Sekolah Tinggi

Perikanan Jurusan Penyuluhan

Perikanan.

Putuhena, Jusmy D. 2011. "Perubahan

Iklim dan Resiko Bencana pada Wilayah Pesisir dan Pulau-Pulau Kecil." Hal. 287-98 in Prosiding Seminar Nasional Pengembangan Pulau-Pulau Kecil 201. Maluku (ID): Universitas Patimura.

Ramadoan, Sri, Pudji Muljono, dan Ismail Pulungan. 2013. "Peran PKSM dalam meningkatkan Fungsi Kelompok Tani dan Partisipasi Masyarakat di kabupaten Bima NTB." Jurnal Penelitian Sosial dan Ekonomi Kehutanan 10(3):199210.

doi: 10.20886/jpsek.2013.10.3.199-210. Yuniarti, Tatty, Alvi Nur Yudistira, dan Hendria Suhrawardhan. 2011. "Pembuatan Bakso Ikan Lele (Clarias sp) Warna Warni Sebagai Alternatif Jajanan Anak Sekolah." Jurnal Penyuluhan Perikanan dan Kelautan 5(1):35-42. doi: 10.33378/jppik.v5i1.28. 